\title{
CIVILIZAR O CAMPO: EDUCAÇÃO, SAÚDE E INICIAÇÃO PROFISSIONAL NOS CURSOS DE ALFABETIZAÇÃO DA PROFESSORA ZILMA COELHO PINTO, NO ESTADO DO ESPÍRITO SANTO (1947-1963)
}

\author{
CIVILIZING THE FIELD: EDUCATION, HEALTH AND \\ PROFESSIONAL INITIATION IN TEACHER ZILMA COELHO \\ PINTO'S COURSES OF LITERACY, IN THE STATE \\ OF ESPÍRITO SANTO (1947-1963)
}

\author{
CIVILIZAR EL CAMPO: EDUCACIÓN, SALUD E INICIACIÓN \\ PROFESIONAL EN LOS CURSOS DE ALFABETIZACIÓN DE LA \\ PROFESORA ZILMA COELHO PINTO, EN EL ESTADO \\ DO ESPÍRITO SANTO (1947-1963)
}

\author{
Deane Monteiro Vieira Costa ${ }^{\mathrm{I}}$ \\ IInstituto Federal do Espírito Santo (IFES), Vila Velha/ES - Brasil.
}

\begin{abstract}
Resumo Este trabalho é resultado de pesquisa que teve por finalidade investigar, numa perspectiva histórica, a trajetória de vida da professora Zilma Coelho Pinto e do seu planejamento pedagógico em favor da alfabetização, assistência social e profissionalização, durante a primeira Campanha de Educação de Adolescentes e Adultos (CEAA), criada pelo Ministério da Educação e Saúde Pública, no Brasil. A partir de ampla pesquisa de fontes documentais, como: jornais, revistas, relatórios de governo e entrevistas com familiares e auxiliares da Campanha, foi possível analisar que a alfabetização proposta pela professora Zilma envolveu outros conteúdos, a saber: valores e comportamentos pautados em preocupações com a higiene, a saúde e a moral. As lições de civilização de Zilma, como constatamos, tinham como destinatários os alunos. A fim de desenvolver a nossa pesquisa, recorremos ao conceito de Processo Civilizador de Norbert Elias $(1993,1994,1997)$ para compreender a CEAA e a atuação da alfabetizadora Zilma como um campo de ação
\end{abstract}


da organização sanitária moderna por meio de um "ethos" de civilidade, que focalizou o atendimento aos adolescentes, jovens, adultos, pobres, mestiços e analfabetos no Estado do Espírito Santo.

Palavras-chave: Campanha de Alfabetização; Educação Rural; Iniciação Profissional; HistóRIA DA EduCAÇão.

Abstract This study is the result of a research that aimed to investigate, in a historical perspective, the life trajectory of the teacher Zilma Coelho Pinto and her pedagogical planning in favor of literacy, social assistance and professionalization, during the first Adolescent and Adult Education Campaign (CEAA), created in the 1940s, by the Ministry of Education and Public Health in Brazil. Based on extensive research on documentary sources such as: newspapers, magazines, government reports and interviews with family members and assistants of the campaign, it was possible to analyze that the literacy proposed by Zilma involved other contents, such as values and behaviors concerns about hygiene, health and morals. The lessons of civilization had, in the students, the recipients. In order to do this, we used Norbert Elias's concept of Civilizing Process $(1993,1994,1997)$ to understand the CEAA and Zilma's literacy work as a field of action of the modern sanitary organization through an ethos of civility, which focused on providing services to adolescents, young adults, adults, the poor, mestizos and illiterates, in the State of Espírito Santo.

Key-words: Literacy Campaign; Rural Education; Professional qualification; History of EDUCATION.

Resumen Este estudio presenta la historia de vida de la profesora Zilma Coelho Pinto y de su planificación pedagógica en favor de la alfabetización, asistencia social y profesionalización, durante la primera Campaña de Educación de Adolescentes y Adultos (CEAA), creada por el Ministerio de Educación y Salud, en Brasil. Los diversos textos de la CEAA fueron producidos por el Sector de Orientación Pedagógica del Servicio de Adultos del Ministerio y destinados a las Secretarías de Educación de los diversos Estados, a los profesores, a los voluntarios así mismo a los jóvenes y adultos alumnos de la Campaña. En ellos, se presentó la educación como una palanca capaz de edificar una nueva sociedad, en tiempos de redemocratización, en la década de 1940. La alfabetización pasó a ser identificada como un campo de acción de la organización sanitaria moderna por medio de un "ethos" de civilidad, en aquel entonces en el área de educación de jóvenes y adultos. De este modo, fue posible encontrar una noción bien particular de "civilización", tomada por la CEAA y por las profesoras voluntarias, especialmente en el caso específico de la profesora Zilma, para atender a los pobres y analfabetos de su municipio. Para llegar a esas conclusiones, tomamos como referencia el concepto de Proceso Civilizador de Norbert Elias (1993, 1994, 1997) y además a los estudios de la historia de la educación brasileña que se utilizan de ese aporte teórico.

Palabras clave: Campaña de Alfabetización; Educación rural; Formación profesional; Historia de LA EDUCACIÓN. 


\section{INTRODUÇÃO}

Zilma Coelho Pinto sonhou [com] um Brasil sem analfabetos - e está [estava] fazendo a sua parte. Essa professora e isso que ela está fazendo em Cachoeiro de Itapemirim é algo que será contado muito tempo depois de nós. Mesmo que acabasse hoje, como está, tudo o que aí está realizado: uma legenda heroica diria o significado.

É uma empreitada de horário integral. Cada dia, cada hora, cada minuto. Viaja, pede, zanga, fala, constrói desinteresse e má vontade, burocracia [...].

Incansavelmente, abnegadamente, o objetivo compensa tudo, [pois] os frutos de cada safra valem a tarefa do desbravamento, do deslocamento, do arroteamento, da semeadura, das inclemências do tempo, da labuta da colheita.

Homens, mulheres e crianças estão sendo alfabetizadas às centenas. Hábitos de higiene, noções de civilidade e de responsabilidade pessoal, habilitações profissionais, tudo isso está sendo criado por obra e alma de uma professora de boa vontade.

O trecho citado foi retirado de um pequeno recorte de jorna ${ }^{1}$ guardado pela família da professora Zilma Coelho Pinto. Ele faz parte de um acervo composto de documentos pessoais, cartas, notícias, fotos, certificados, "miudezas", "detalhes" e "fios" de uma totalidade que compõe a história de vida de uma professora que participou ativamente da primeira Campanha de Educação de Adolescentes e Adultos (CEAA), um marco importante no processo de constituição do campo teórico-prático da área de educação de jovens e adultos no Brasil (GINZBURG, 2002).

De acordo com Fávero (2004), a educação de adultos e, particularmente, a alfabetização de adultos tem uma história longa no Brasil, embora somente seja assumida como um problema nacional a partir de meados dos anos de 1940. Assim, a década de 1940 é marcada pelos primeiros movimentos voltados para a extensão do ensino às grandes massas de jovens e adultos analfabetos. Esses movimentos respondiam às características típicas atribuídas aos processos da "educação para o povo", que pressupunha a necessidade de educar todos os habitantes de um país.

A CEAA funcionou durante o período compreendido entre 1947 e $1963 .^{2}$ De acordo com Paiva (1983, p. 191), durante o ano de 1962 “[...] em face da contenção do orçamento e de motivos políticos e administrativos - ela praticamente não desenvolveu suas atividades".

Ainda assim, a primeira Campanha de Educação de Adolescentes e Adultos foi um marco importante no processo de constituição do campo teórico-prático da área de educa-

1 O recorte não tinha qualquer identificação, a saber: nome do impresso, período de publicação e autoria. Foi encontrado com Carlos Luís Pinto, filho da professora Zilma Coelho Pinto, que, desde a sua infância, acompanhou o desenvolvimento da CEAA e a atuação de sua mãe na direção dos trabalhos. Apesar do nosso empenho investigativo, não encontramos a origem do recorte de jornal. Para Carlos, o texto era dos anos de 1950, auge da atuação da professora Zilma na CEAA.

2 Na prática, caracterizava-se pela alfabetização em três meses. O curso primário tinha duração de dois períodos de sete meses, seguidos de ações de desenvolvimento comunitário e de treinamento profissional (PAIVA, 1983). 
ção de jovens e adultos. A extensão territorial que a CEAA abrangeu, "[...] o período em que se desenvolveu e o material de fundamentação que produziu já justificariam o investimento feito em pesquisas por interessados na temática" (SOARES, 1995, p. 51).

Apesar de sua importância, existe uma escassez de estudos sobre a CEAA e suas implicações para os vários Estados brasileiros. As exceções são: a) o trabalho pioneiro realizado por Beisiegel, publicado pela primeira vez em 1974 e que descreveu o desenvolvimento da CEAA no Estado de São Paulo; e b) o estudo de Soares (1995) que descreveu o desenvolvimento da Campanha de alfabetização em Minas Gerais. Com vistas à ampliação dos estudos já existentes, este trabalho pretende contribuir com a construção de um entendimento histórico sobre as particularidades do desenvolvimento da CEAA no Estado do Espírito Santo (COSTA, 2012; 2016).

Historicamente, a educação rural sistematizada teve como marco a década de 1920, quando a elite brasileira passou a se preocupar com a crescente migração rural-urbana, que poderia desestabilizar o mundo social, agravada pela desqualificação profissional dessa população migratória. Desse modo, a valorização do meio rural deu-se por intermédio da educação, orientada pelo ruralismo pedagógico - tendência importante entre as décadas de 1930 e 1940 -, que valorizou a escola primária na área rural, com a finalidade de inculcar a permanência da população campesina. No entanto, em meados dos anos de 1940, o ruralismo pedagógico perdeu importância teórica e prática. A educação rural tornou-se pauta nas campanhas comunitárias, fundamentadas no desenvolvimento da comunidade do campo aos moldes da existência de vida, conhecido como urbanizado.

Nesse contexto, o papel do professor rural, como "guia da comunidade", dava-se na medida em que ele se responsabilizava por "[...] elevar o nível de vida das populações campesinas". E a escola significaria um "centro cultural do vilarejo", talvez com uma importância maior que a paróquia local (LOURENÇO FILHO, 1953). ${ }^{3}$

Diante da educação rural, cabe-nos destacar a trajetória da professora Zilma Coelho Pinto, que foi marcada por esse movimento e que dava ao professor das comunidades rurais uma moldura de "guia da comunidade" (ou seja, aquele que indica os caminhos a serem trilhados). Sua trajetória foi marcada também pela construção do discurso educacional da CEAA, realizado por Lourenço Filho (1950). ${ }^{4}$ Esse discurso apresentava o professor como "guerreiro e soldado", que estaria diante de uma cruzada contra o inimigo - o analfabetismo.

A participação ativa da professora Zilma na CEAA construiu uma boa relação entre ela e o professor Lourenço Filho. Nos documentos pessoais arquivados por sua família, foi encontrada uma carta enviada e assinada por Lourenço Filho, que acreditamos se tratar de um prefácio de um livro sobre a campanha dirigida pela professora. Nela, Lourenço Filho não mede palavras para elogios à atuação de Zilma.

Texto intitulado La formation des maîtres ruraux, publicado pela UNESCO em 1953.

4 Alguns educadores, como Lourenço Filho, tiveram um papel importante no processo de sistematização, de idealização e de gestão da CEAA. No periodo de 1947-1950, ele ocupou o cargo de diretor-geral na primeira fase da Campanha. 
No ano de 1950, período em que Lourenço Filho ainda era diretor-geral da Campanha, a professora Zilma recebeu de suas mãos a condecoração de maior calibre em seu currículo profissional: a Medalha de Ouro e o Diploma de "Honra ao Mérito" da Cia. Stander Oil do Brasil, solenidade na época transmitida pela Rádio Nacional do Rio de Janeiro.

Apresentar a vida dessa professora que se projetou na CEAA dando asas ao pensamento do peso político da ação educativa da mulher no seio da pátria é relevante para se compreender melhor o ensino rural brasileiro nos anos de 1947-1963. Tal ensino se deu por meio das histórias e memórias dos professores rurais, pois “[...] uma mirada sobre o ensino rural parece demasiado incompleta se não refletirmos um pouco mais sobre os professores rurais" (ALMEIDA, 2005, p. 291).

Trata-se, portanto, de uma pesquisa sobre a história de vida da professora Zilma Coelho Pinto e do seu minucioso planejamento pedagógico em favor da alfabetização, assistência social e profissionalização, demarcado por uma noção de "civilização" tomada por ela e pelas professoras voluntárias para atender aos pobres e analfabetos de seu município. A partir de uma ampla pesquisa em fontes documentais - como jornais, revistas, relatórios de governo e entrevistas com familiares ${ }^{5}$ e auxiliares ${ }^{6}$ da Campanha - foi possível analisar a perspectiva educativa adotada pela professora Zilma, uma perspectiva que procurava abrandar costumes com vistas a interagir com os hábitos sociais existentes e desejados na construção do homem brasileiro civilizado.

A fim de cumprir com os nossos objetivos, recorremos ao conceito de Processo Civilizatório de Norbert Elias $(1993,1994,1997)$ e aos estudos da história da educação brasileira. Vamos nos pautar em torno de dois eixos. O primeiro eixo corresponde à biografia da professora Zilma, com destaque para a sua participação direta na CEAA. E o segundo eixo corresponde à criação de uma entidade sem fins lucrativos, denominada de Campanha de Alfabetização e Assistência Social de Cachoeiro de Itapemirim (CAASCI), que focalizou o atendimento aos adolescentes, jovens e adultos, pobres e analfabetos de sua cidade.

5 Foi entrevistado, inicialmente, Carlos Luis Pinto, filho da professora Zilma Coelho Pinto, que acompanhou o desenvolvimento da CAASCI e a atuação de sua mãe na direção dos trabalhos, desde a sua infância. Na ocasião, apresentou um acervo de documentos pessoais, cartas, notícias, fotos e certificados da história da alfabetizadora. Conversamos, de modo informal, com a neta da professora Zilma Coelho Pinto, Luilma Pinto Mendonça e com a sua mãe, Neiva de Oliveira Pinto, que foi casada com Luis Carlos Pinto.

6 A segunda entrevista foi realizada com o cientista social Sidney Gonçalves Netto Jordão, que, entre os anos de 1985 e 1986 atuou como voluntário na CAASCI, trabalhando na organização da biblioteca da entidade, que, segundo ele, era a maior em tamanho e em acervo no município de Cachoeiro de Itapemirim. O contato com a entidade e a sua presidente Zilma Coelho Pinto fez que ele e mais dois colegas de curso (Carlos Geraldo Carvalho e Elza Helena da Silva), que também atuavam como voluntários na entidade, escolhessem, como tema de conclusão de curso: Zilma Coelho Pinto e a Campanha de Alfabetização. Pesquisa defendida em 4 de julho de 1986, na Faculdade de Filosofia, Ciências e Letras "Madre Gertrudes de São Jose". A narrativa é construída pela própria professora Zilma, por meio de entrevistas concedidas aos alunos pesquisadores, de julho a dezembro de 1985, na ocasião, tinha 76 anos de idade. 


\section{Vida E trajetória Profissional da Professora Zilma Coelho Pinto}

Zilma Coelho Pinto nasceu em 31 de março de 1909, em Cachoeiro de Itapemirim, cidade localizada na região sul do Estado do Espírito Santo. Essa cidade, durante a vigência da Primeira República (1889-1930), desempenhou um importante papel "[...] de centro econômico, cultural e político, sendo mesmo, nesse período, em alguns momentos, mais importante do que a capital" (SILVA, 1995, p. 111).

A região sul do Espírito Santo consolidou-se historicamente ao longo da expansão cafeeira dos diversos núcleos urbanos que foram influenciados por Cachoeiro de Itapemirim, que, por sua vez, se mantinha influenciado pela cidade do Rio de Janeiro. Nesse sentido, Cachoeiro de Itapemirim esteve, ao longo de sua história, "[...] mais suscetível às influências políticas e culturais do Rio de Janeiro do que da capital do Espírito Santo - Vitória" (SILVA, 1995, p. 111). ${ }^{7}$

A educadora era filha de José Coelho Ferreira, proprietário rural e um dos administradores das indústrias de Cachoeiro de Itapemirim no governo de Jerônimo Monteiro (19081912), e de Julita Moreira Coelho, dona de casa. A gestão de Jerônimo Monteiro transformou o vale do rio Itapemirim em polo de desenvolvimento econômico do Estado,

[...] para aproveitar as matérias-primas extraídas ou produzidas na região, al-
gumas empresas foram montadas em Cachoeiro: fábrica de tecidos, de cimento,
de papel, de óleo vegetal e uma serraria industrial. No Baixo Itapemirim, foi
instalada uma usina de beneficiamento de açúcar. No Rio Fruteiras, afluente
localizado no Alto Itapemirim, uma usina hidrelétrica foi construída, gerando
energia para todo o 'distrito industrial' (SCHAYDER, 2002, p. 91).

Para a administração dos recursos dos variados investimentos era preciso convocar homens da região com experiência em gestão de negócios. José Coelho Ferreira, pai da professora Zilma, foi um desses homens convidados pelo governador Jerônimo Monteiro.

Além desse perfil desbravador, os pais de Zilma eram cuidadosos com a formação intelectual, moral e religiosa dos filhos. Segundo uma entrevista dada pela professora Zilma Coelho Pinto (1986, p. 5), seus pais eram religiosos, sua mãe era "[...] dada ao espiritismo e seu pai ao catolicismo. Todos nós não deitávamos, nem levantávamos sem rezar".

No entanto, a morte precoce de seu José Coelho Ferreira fez que dona Julita Moreira Coelho, mãe de Zilma, tivesse que criar seus nove filhos ao lado de sua família, de sobrenome Moreira. De acordo com a biografia fornecida pela Academia Feminina Espírito-santense de Letras, da qual a professora Zilma é patrona da cadeira $\mathrm{n}^{\circ}$. 25, e com o estudo histórico do pesquisador Agostino Lazzaro, intitulado A face múltipla e vária: a presença da mulher na cultura capixaba, Zilma cursou o ensino "[...] primário e ginasial no Colégio

7 A influência política, econômica e social do Rio de Janeiro sobre Cachoeiro de Itapemirim pôde ser percebida antes da proclamação da República, com a circulação dos ideais republicanos e da criação de um clube republicano pelos filhos de proprietários rurais de Cachoeiro de Itapemirim que voltavam de seus estudos realizados no Rio de Janeiro, em fins do século XIX (ver COSTA, 2000). 
Nossa Senhora Auxiliadora em Vitória e o curso normal, no Colégio Pedro Palácios, em Cachoeiro de Itapemirim" (LAZZARO, 1994, p. 115).

O Colégio Nossa Senhora Auxiliadora, conhecido como o "O Carmo", foi fundado graças à ação do bispo Dom João Nery, que, em 20 de novembro de 1889, firmou um acordo com a visitadora das filhas de São Vicente de Paulo, para que as irmãs pudessem dirigir um educandário na capital do Estado, “[...] no ano seguinte, chegaram a Vitória três religiosas, que se estabeleceram no velho prédio do Carmo" (FRANCO, 2011, p. 316).

Ainda de acordo com Franco (2011, p. 317), a formação oferecida a essas moças era rígida e seguia os preceitos católicos e os valores morais conservadores da época. Para isso, "[...] era ofertada a disciplina de História - sobretudo a Sagrada e a Antiga", inculcando valores de preparo ao exercício das funções de mãe e esposa. As disciplinas de Geografia e Ciências Físicas e Naturais eram ofertadas "[...] como forma de garantir a cultura geral das alunas, mais nunca como centro da instrução".

No contexto dessa discussão sobre a formação inicial da professora Zilma realizada no "Colégio do Carmo", podemos problematizar: de que maneira a sua formação no Colégio do Carmo contribuiu com o exercício de sua profissão? Quais as relações existentes entre as campanhas de alfabetização e sua formação religiosa?

De acordo com Graff (1994), o importante vínculo entre alfabetização e religião forma um dos legados mais vitais (ainda que às vezes, mas nem sempre, conservador) na história da humanidade, sendo as reformas do século XVI, tanto protestantes quanto católicas, os exemplos mais marcantes desse fenômeno. No entanto, destaca o mesmo autor (1994) que o impulso religioso para a leitura, tendo como objeto a propagação da piedade e da fé, antecede muito aàquela época, “[...] sua história está estreitamente ligada à história da cristandade ocidental e as contradições dentro de uma, são com frequência as da outra" (GRAFF, 1994, p. 42). Dessa forma,

\footnotetext{
[...] a alfabetização serviu para registrar desde tempos imemoriais a Palavra, mas sua influência e difusão vieram, por séculos, de forma avassaladora, através dos meios orais de ensino e pregação. Entretanto, muitos que nunca vieram a pertencer ao clero aprenderam suas letras através das agências da igreja cristã medieval universal, usando-as para o serviço do Estado, do comércio, das letras ou para seu próprio benefício. Isso não se constituiu necessariamente num fim conservador (GRAFF, 1994, p. 42).
}

A motivação religiosa, na base da trama social que forja concepções de educação, de homem e sociedade, pode também ser encontrada na história do Brasil. De acordo com Azevedo (1981, p. 11),

[...] a invocação do nome de Deus na lei, o emprego de linguagem religiosa, a participação ou a promoção de ritos litúrgicos, a associação de sacerdotes a funcionários seculares em cerimônias civis e militares, a observância de dias santificados, a exposição de imagens ou símbolos religiosos em recintos e lugares públicos, as declarações de acatamento da religião e de seus representantes, 
por parte do Estado, são interpretados, ordinariamente, como manifestações de um Estado religioso e mesmo confessional, que apóia ou incorpora a religião da população, ou são tidos como evidências de boas relações com as instituições [...] religiosas.

Nesse sentido, apesar de todo o movimento de secularização da sociedade e do Estado a partir da redemocratização do regime republicano brasileiro vivido pelo país, naquele contexto de idealização da CEAA, a credibilidade na alfabetização, como crença salvífica na transformação social, difundida nos diversos textos e produções da CEAA, revelou, em muitos casos, o peso da influência religiosa.

Isso justifica o destaque no cultivo da caridade na constituição do voluntariado e na composição de doações para a manutenção da campanha no caráter educativo mediante o exemplo, na divulgação do modelo unívoco de família baseado nos valores cristãos, na defesa do trabalho, no combate aos vícios e, por último, a ênfase na educação da mulher para educar a família (COSTA, 2012; 2016).

Assim, a pressa em alfabetizar por parte das alfabetizadoras, professoras e voluntários era a resposta dada às exigências justas e profundamente cristãs que marcavam o cenário político-ideológico daquele período. Desse modo, a professora Zilma dedicou-se sobremaneira à alfabetização de crianças e adultos de sua cidade e das comunidades rurais afastadas daquela região, antes mesmo da criação da CEAA. De acordo com a monografia Zilma Coelho Pinto e a Campanha de Alfabetização (CARVALHO; SILVA; JORDÃO,1986, p. 2),

[...] o gosto por este trabalho advém de suas raízes interioranas e das muitas experiências vividas entre gente simples que sofria por não ler. Isto aconteceu em sua casa: um senhor com as receitas de remédio de seu filho, havia caminhado légua para que Zilma lesse o que estava escrito. O homem não sabia ler e pedia-lhe ajuda. A falta de leitura deixava-o sem saber como. Descobre que onde morava esse pobre homem ninguém sabia. Incentiva-o a mandar as crianças de sua vizinhança para que ela as ensinasse. A distância era longa. O que faz ela? Passou então a ir uma vez por semana, o dia inteiro, reunindo toda criançada do lugarejo para ensiná-las a ler e escrever. Desde então, não parou mais de lutar contra a praga do analfabetismo, tão fatal quanto às doenças de massa.

Carlos Luis Pinto comenta que, quando sua mãe "[...] começou a lecionar tomou gosto pelo ensino e se apaixonou pelo ensino. Virou um idealismo dela". Mas Zilma não alfabetizou nem ele nem sua irmã, Luma. Quem o alfabetizou foi uma amiga de sua mãe, Dona Verônica, que "[...] era tão brava quanto Zilma. Zilma era muito brava, ela ganhava no grito e com a sua personalidade forte. Mas, nunca agrediu nenhum de seus alunos". No entanto, afirma Carlos que Dona Verônica, ao contrário, "[...] descia a palmatória na gente".

Em uma de suas recordações, Carlos Luis Pinto conta, emocionado, que teve uma conversa com sua mãe sobre as dificuldades que enfrentava nos estudos iniciais, apontando que a sua luta pela alfabetização dos "outros" poderia acarretar no analfabetismo de seu filho. 
Eu reclamava com ela que eu fui abandonado. A senhora deixou a maior obrigação que a senhora tinha, que era alfabetizar seu filho, você deixou ele analfabeto. Ela tinha sempre uma saída: 'Pra você ver qual é o meu valor. Abandonei o ente mais querido da minha vida por milhares...'

Carlos Luis Pinto conclui o trecho fitando os olhos na pesquisadora e perguntando: "[...] Quem podia? Vai discutir o quê?" E emocionado, afirma: “[...] Era o idealismo dela". Esse idealismo pode ser compreendido a partir do seu envolvimento com a educação das comunidades rurais de seu município, que projetava, em sua posição de alfabetizadora/ professora a valorização de "guia", "líder" e "autoridade". Ao trabalhar como professora numa fazenda de Santana do Itabira,

[...] onde lhe deram para começar uma sala vazia e um punhado de meninos. E desde aquele dia, ela habituou a receber sempre as coisas vazias, para ter que enchê-las com o seu esforço e dedicação. Foi sempre, com a ajuda das próprias crianças, que acabou de construir as próprias escolas, endireitando bancos toscos, arranjando mesas quebradas, recompondo livros desfolhados. Em muitas ocasiões, ela teve que fazer cadernos para os alunos com folhas de papel de embrulho, ficando muitas noites em claros, onde as folhas eram passadas a ferro e costuradas, para que o aluno pobre pudesse escrever (SILVA, 2009, p. 6).

Da abolição da escravatura até metade da década de 1950, a economia estadual era totalmente dependente da cafeicultura desenvolvida com base em um sistema de pequenas propriedades familiares e autossuficientes, o que desfavoreceu a concentração de capital e alterações de monta na estrutura produtiva (ROCHA; MORANDI, 1991). De acordo com Costa (1997, p. 396):

[...] em 1946, de uma população de 850.000 habitantes havia 52.272 matrículas nas escolas de ensino primário e os cálculos oficiais estimavam em 70.000 o número de crianças fora da escola primária, a taxa de analfabetismo era de $54,21 \%$, mais da metade dos docentes do ensino primário eram leigos e nomeados por favorecimentos políticos (as chamadas cooperadoras de ensino), as instalações físicas eram em número insuficiente e inadequadas, os vencimentos eram baixíssimos, não existia um plano de carreira para o magistério e o ensino secundário estava concentrado na iniciativa privada, pois de 28 estabelecimentos de ensino, apenas 3 (cerca de 10\%) eram oficiais.

Foi nesse contexto que se deu a participação da professora Zilma na Campanha de Educação de Adolescentes e Adultos, promovida pelo Ministério da Educação e Saúde. Isso ocorreu quando ela, ouvindo e lendo os jornais que divulgavam os feitos e realizações de voluntários empenhados com a CEAA, assumiu, espontaneamente, o movimento de sua cidade (MACIEL, 2003). De acordo com o mesmo autor, a professora Zilma

[...] caminhou por toda a cidade, desde as margens do rio até aos escarpados dos morros, batendo de casa em casa, à procura de salas, cômodos vazios, bar- 
racões, enfim um cantinho qualquer onde pudesse reunir um grupo de pessoas para serem alfabetizadas. Desse modo, conseguiu dar início ao seu intento (MACIEL, 2003, p. 285).

A partir daí, a professora Zilma trabalhou incessantemente por doações e apoio em prol do projeto já iniciado. Curiosamente, a residência de Dona Zilma virou a sede da Campanha, onde se guardavam os materiais didáticos doados e/ou enviados pelo Ministério da Educação e Saúde, pela Secretaria Estadual de Educação e Cultura e por entidades filantrópicas. Além disso, o local também foi utilizado como ponto de encontro do professorado envolvido na Campanha, a fim de planejar e discutir as próximas ações.

Carlos Luis Pinto também relembra o fato de sua casa ter se tornado o "escritório" da Campanha e apontou dificuldades trazidas para a família, quando seu pai se queixava da falta de privacidade em seu lar:

[...] ele, às vezes, reclamava. É uma questão de que nossa casa, muitas vezes, nós perdíamos a nossa privacidade. Muitas vezes, tinha uma mesa grande lá em casa que almoçava vinte, trinta pessoas, professoras... Na hora do almoço, muitas vezes, não tinha aquela privacidade para conversar. E minha mãe, levou no começo, levou a Campanha pra dentro de casa. Tinha dois cômodos ocupados dentro de nossa casa, era o escritório da Campanha, pilhas e mais pilhas de documentos, doações, livros, tudo lá dentro. Depois meu pai construiu, nos fundos de nossa casa, uma casinha de madeira com dois cômodos, pensando que ia aliviar dentro de casa, mas não. Continuou...em vez de dois cômodos, passou a quatro cômodos... e isso atrapalhava a gente.

No entanto, de acordo com a professora Zilma, "[...] muitos preconceitos e tabus" ela teve que superar na sua época por ser mulher (CARVALHO; SILVA; JORDÃO, 1986, p. 8). Lembrou-se do seu primeiro discurso pronunciado em cima de um banco na praça Jerônimo Monteiro, onde reuniu em torno de si várias pessoas que passavam no local. Ali, batendo com as mãos "[...] colocava ao público, o seu ideal de exterminar o analfabetismo e assistência social que desejava implantar com a Campanha" (CARVALHO; SILVA; JORDÃO, 1986, p. 8).

Com esse discurso, conseguiu um salão na fábrica de Cimento Nassau, com a finalidade de abrir um curso de alfabetização para os filhos dos operários dessa fábrica. Por sugestão de algumas pessoas, escreveu para Carlos Lindenberg, que era governador do Espírito Santo naquele período, "[...] pedindo-lhe para doar uns pedaços de carteiras que haviam na Escola Quintiliano de Azevedo, para serem recuperadas e utilizadas" (CARVALHO; SILVA; JORDÃO, 1986, p. 8).

Depois de sua exposição, a professora Zilma conseguiu também receber a adesão de alunas - como professoras voluntárias -, a colaboração da comunidade e a participação dos próprios alunos. De acordo com Maciel (2003), com o empenho e a dedicação dessas professoras comandadas por Zilma o município de Cachoeiro de Itapemirim destacou-se na década de 1940 e 1950, “[...] na vanguarda da luta contra o analfabetismo" (MACIEL, 2003, p. 286). 
Assim, em junho de 1948, num jornal da região ${ }^{8}$ foi noticiado pelo repórter Gilson Carone o funcionamento de 11 escolas em diversos locais de Cachoeiro de Itapemirim. Essas escolas foram cedidas por industriais, empresários e líderes religiosos. Muitas vezes as escolas funcionavam nas casas das próprias professoras e contavam com o apoio de voluntárias, como: Antônia M. Cardoso, Izabel Pinheiro Cordeiro, Luiza X. Lima, Maria José Moreira, Maria de Lourdes Jacinto, Maria Vivaqua Vieira, Sebastiana P. de Matos, Vera Carias e Zelina Moraes. A notícia ia narrando o cotidiano e a composição dos/as alunos/as dessas classes.

$\mathrm{Na}$ Serraria Industrial ficava localizada uma escola de alfabetização [...] como seus alunos são pequenos trabalhadores da madeira, resolveram as professoras denominá-la Escola "São José" como uma homenagem ao santo carpinteiro. No Salão do Cruzador, a Campanha criou duas escolas (diurna e noturna). No curso noturno os alunos, na maioria, são trabalhadores da Serraria da Fábrica de Cimento etc.

[...] e é interessante acentuar que entre outros cursantes já idosos, há uma cuja idade é de 49 anos. Entre os menores que estudam no curso da manhã [...] muitos há que esmolam pelas nossas ruas. Também na fábrica de Tecidos e no Centro Espírita da rua 25 de Março, funcionam escolas de alfabetização, sendo que na primeira existe apenas o curso noturno e na segunda, também o diurno. Como em todas as outras por nós visitadas, estas escolas já contam com um bom número de alunos, pobres em sua totalidade. No Aquidabã existem 3 pequenas escolas de alfabetização que somam o total de 65 alunos matriculados e que funcionam nas próprias casas de suas professoras. Assim é que nos lares de D. Sebastiana P. de Matos onde funcionam um curso noturno e um diurno, e no da Srta. Maria de Lourdes Jacinto, os alunos reúnem-se nas salas das referidas casas, buscando nas explicações das modestas professoras, a luz do saber (CARONE, 1948, s/p.).

De acordo com a professora Zilma (CARVALHO; SILVA; JORDÃO,1986, p. 9), “[...] não havia profissionais que se dispusessem a trabalhar em horários noturnos, sendo assim, foi necessário preparar uma equipe de pessoas simples, mas que lutassem pelo mesmo ideal". Então, inicialmente, foi organizada uma sala de aula "[...] com 40 alunas-professoras para juntos planejarem e estudarem um método rápido de alfabetizar" (CARVALHO; SILVA; JORDÃO, 1986, p. 9).

Dessa forma, nas palavras finais da professora Zilma, tratou-se de "[...] um trabalho de grande esforço, pois na época não existia e nem se falava em alfabetização de adultos" (CARVALHO; SILVA; JORDÃO, 1986, p. 9). E acrescentou que não foi possível, para a instalação da obra como a campanha, "[...] a elaboração e a realização de uma pesquisa para que esta nascesse numa base científica; nasceu do que foi possível" (CARVALHO; SILVA; JORDÃO, 1986, p. 9).

8 Jornal não identificado, pois se trata de um recorte feito pela própria professora Zilma Coelho Pinto, com a intenção de arquivar notícias locais sobre a atuação do projeto de alfabetização que ela liderou. 
Podemos destacar que o movimento na criação de classes de alfabetização contou com a solidariedade social de empresários, industriais, cidadãos e de líderes religiosos motivados pela crença exaltada e coesiva do processo civilizatório da população brasileira via alfabetização. A escola São José e as classes criadas no Centro Espírita, citadas na reportagem de Gilson Carone (1948), sugerem que o apelo ao voluntariado sob interpretação estatal foi um recurso simbólico destinado a dirigir a ação e as energias coletivas ambíguas e contraditórias do jogo social, inclusive não fazendo distinção de credo entre os voluntários da CEAA.

Essa reportagem foi concluída convocando o restante da população cachoeirense para apoiar a luta contra o analfabetismo na região. Além disso, os elogios e méritos dados à atuação da professora Zilma já a destacavam como a líder daquele movimento local. Quanto às figuras políticas da região, a reportagem concluiu " [...] que pouco fizeram pela alfabetização do seu povo até aquele momento" (CARONE, 1948, s/p.). E que só podia ser "[...] obra da 'Louca do Itapemirim' que sonhou pregar tabuletas pelo Brasil afora com os dizeres: NESTA CASA NÃO HÁ ANALFABETOS” (REVISTA BOAS NOTÍCIAS, 1965, $\mathrm{s} / \mathrm{p}$ ) (Figura 1).

Figura 1 - Tabuleta utilizada pela professora Zilma para apontar as residências alcançadas pela CAASCI

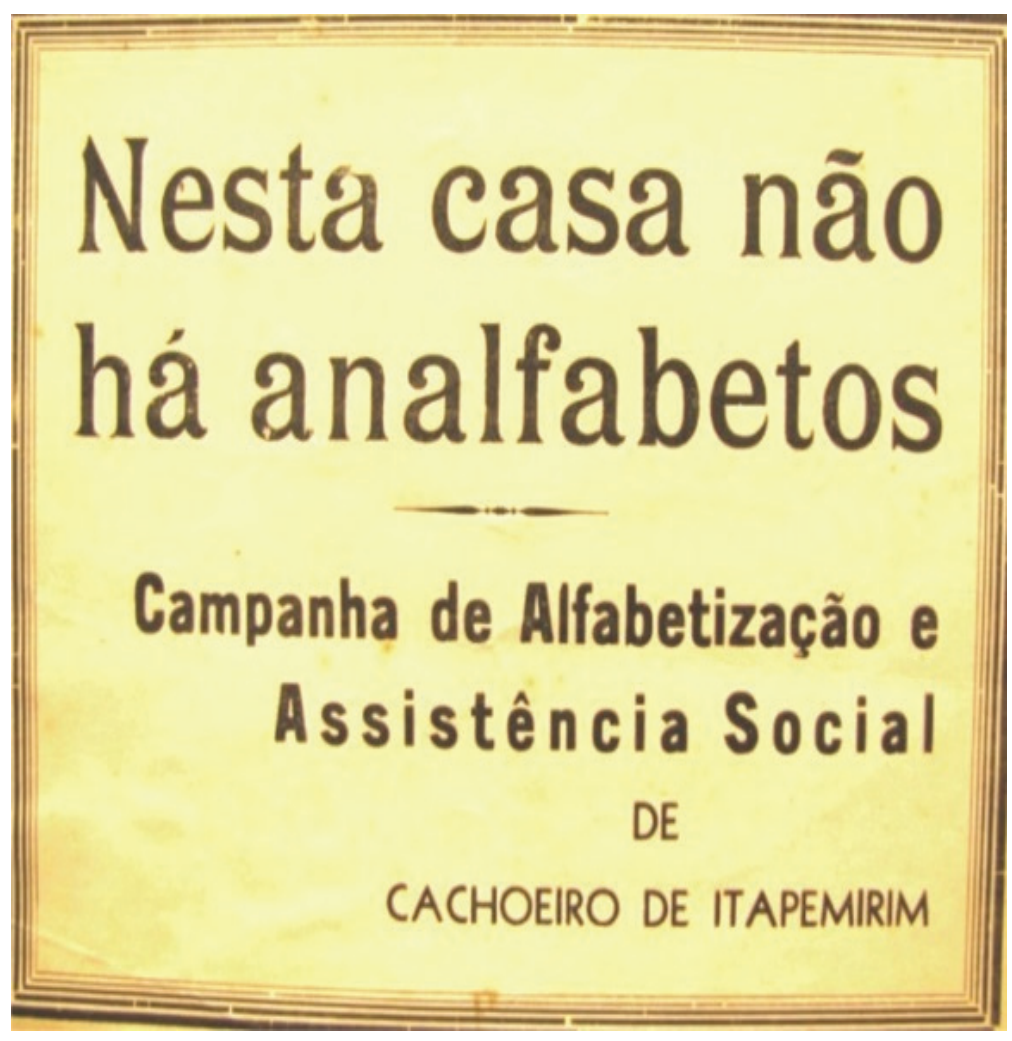

Fonte: Arquivo Familiar 
A composição étnica e social das classes de alfabetização criadas pela professora Zilma e suas colaboradoras gerou muitos comentários e preconceitos por parte da população rica e urbana de Cachoeiro de Itapemirim. De acordo com Zilma, "[...] muitas vezes chegaram a the dizer que suas salas estavam cheias de negrinhos e negrinhas" (CARVALHO, SILVA \& JORDÃO, 1986, p. 14). Teve, ainda, que tolerar as críticas mais "injustas", como as de estarem "[...] pervertendo o povo e tirando-lhe a sua felicidade, tentando alfabetizá-los. Ensinar os pobres seria, segundo muitos, ensiná-los a 'perseguirem os ricos'. As donas de casa, também receavam ficar sem cozinheiras" (CARVALHO; SILVA; JORDÃO, 1986, p. 22).

Tais ações eram manifestadas numa urgência de transformação da realidade e para isso procuraram contribuir. Nesse sentido, para essas professoras, a civilização não seria um estado, mas um processo que se deve prosseguir. Aos poucos, passam a referir-se a um padrão universal de moral e costumes. A respeito disso, Elias (1994a) afirma:

\footnotetext{
O processo de civilização do Estado, a Constituição, a educação e, por conseguinte, os segmentos mais numerosos da população, a eliminação de tudo o que era ainda bárbaro ou irracional nas condições vigentes, fossem as penalidades legais, as restrições de classe à burguesia ou as barreiras que impediam o desenvolvimento do comércio - este processo civilizador devia seguir-se ao refinamento de maneiras e à pacificação interna do país [...] (ELIAS, 1994a, p. 62 , grifos do autor).
}

Assim como Elias observa que, na formação dos Estados-Nação como componente do desenvolvimento das sociedades industriais e da ascensão das classes burguesas, a imagem idealizada de nação é orientada para o futuro "que devia seguir-se", para as professoras que atuaram na CAASCI, a imagem idealizada de educação também é orientada para o futuro, como instrumento de afirmação social e nacional.

A educação, então, era apontada como caminho certo para a superação dos graves problemas sociais e para a construção e organização da nação. No caso particular da história de vida da professora Zilma e das professoras voluntárias que trabalharam com ela, a magnitude do papel educativo feminino é destacada mediante o exemplo, ou seja, cabia à mulher educar por meio de seu exemplo. Esse discurso valorizava o papel civilizador do trabalho feminino.

Partindo dessa discussão, é possível afirmar que a proposição da alfabetização da CEAA pode ser parte integrante do curso civilizatório brasileiro já em andamento, que apresentou, desde o século XIX, a escolarização como uma referência civilizatória, nos seus limites de interdependência e das correlações das práticas localistas em desenvolvimento (VEIGA, 2008).

\section{AA Campanha de alfabetizaÇão e assistência social de CaChoeiro de ITAPEMIRIM (CAASCI) NO ESTAdo DDo Espírito SANTo}

Uma forma encontrada pela professora Zilma e pelas demais voluntárias de levar adiante o movimento que elas denominavam de "apolítico", mas de natureza educacional 
e de assistência social, sem sofrer interferências do poder municipal, foi a materialização de uma entidade sem fins lucrativos, que poderia contar com o apoio direto do Governo Federal, da sociedade civil e do empresariado do município e do Estado. ${ }^{9}$

Devido à visibilidade do "nobre" movimento, foi legitimada a criação da CAASCI, que teve os seus estatutos registrados em 11-4-1949, no Cartório do $1^{\circ}$. ofício de Cachoeiro de Itapemirim. A entidade também foi registrada em 23-4-1949, sob nº. 79, no Cartório do Registro Civil de Cachoeiro de Itapemirim. Ela foi considerada de utilidade Pública Municipal pela Lei $n^{\circ} .205 / 52$ e pelo Governo Estadual, pela Lei de $n^{\circ} .741$, de 3 novembro de 1953.

Constam também os seguintes registros da instituição como entidade filantrópica: no Conselho Nacional de Serviço Social - Proc. $\mathrm{n}^{\circ}$. 241.412/71; na Secretaria do Trabalho e Promoção Social do Espírito Santo (SETRAPS), sob o $n^{\circ}$. 00010-Proc. SETRAPS $n^{\circ}$. 00986/70; e, por último, o registro no Fesbem, sob o nº 007 (MACIEL, 2003).

Após a criação da entidade, a campanha passou a gozar de maior prestígio diante da sociedade cachoeirense, e com certa liberdade quanto às interferências das ações políticas locais que pudessem dar cabo ao grande propósito de alfabetizar e assistir socialmente os excluídos do município.

De acordo com o Estatuto da CAASCI, a entidade seria constituída de ilimitado número de associados, pessoas físicas ou jurídicas e teria duração por tempo indeterminado. A finalidade principal da organização seria elevar o nível intelectual da população e dar assistência social ao povo brasileiro, promovendo os meios e métodos necessários à alfabetização de adultos, adolescentes e menores, prestando-lhes, ainda, assistência médica e odontológica. Todos os serviços seriam prestados gratuitamente pela instituição.

A partir desses objetivos traçados no Estatuto da CAASCI, pudemos observar uma das dimensões da obra educativa da professora Zilma, que se traduzia no trabalho diretamente realizado com os jovens e os adultos. Além dos ensinamentos referidos a conteúdos pedagógicos específicos da alfabetização, eram inculcados valores e comportamentos pautados em preocupações com a higiene, a saúde e a moral. Lições de civilização tinham, então, nos alunos, os destinatários.

Nesse sentido, é preciso destacar que a Campanha de Dona Zilma era perpassada por empreendimentos de alcance assistencialista, sanitarista e cívico, pois não se limitava apenas ao ensino da leitura e da escrita aos seus conterrâneos. Buscava também meios para melhorar o nível de vida da população local,

[...] pois sabia perfeitamente que a instrução não bastava, era preciso também combater as doenças e a fome. Quando um aluno de sua classe faltava sem justificativa aparente, de imediato enviava uma professora ao seu domicílio para se informar se era doença ou sem ânimos para estudar (LA LOCA de la escuela, 1950, p. 12).

9 O termo apolítico foi destacado nas entrevistas com Carlos Luís Pinto, filho da professora Zilma Coelho Pinto, e com o professor Wilson Lopes de Resende, amigo da professora Zilma. Ambos se referiam ao termo para descrever a autonomia da entidade (CAASCI) fundada pela professora Zilma, até os anos de 1963, quando recebia verbas do âmbito federal e doações de empresários e civis, sem contar com a interferência dos políticos e partidos locais. 
Combater as doenças oferecia um campo enorme para a atuação dos médicos que, no contexto da CAASCI, foram aqueles que, afinados com a missão educativa da entidade, propuseram medidas de ordenamento do espaço e "purificação" do meio que conduziram a sociedade local, tanto na orientação da vida privada dos indivíduos quanto na vida pública das coletividades. Desse modo, a alfabetização apareceu como sendo uma tarefa "nobre", como a missão preventiva e saneadora da medicina.

O ensino da higiene se efetuava em colaboração com o serviço de saúde do Estado. Dona Zilma tem recorrido ao concurso de médicos, de laboratórios e de dentistas da cidade, que vão aceitando atender gratuitamente a todos os seus alunos. As coletas de produtos têm permitido reunir objetos de todos os tipos com destino aos pobres do lugar: vestidos, artigos de higiene e louças de cozinha, etc. (LA LOCA de la escuela, 1950, p. 12).

Com esse currículo "praticado", acreditava-se que, progressivamente, as novas formas de relações humanas acarretariam em uma mudança importante, onde havia a valorização da "compulsão de policiar o próprio comportamento", ou seja, o aumento da importância do controle do indivíduo sobre os seus próprios atos sociais, o autocontrole em detrimento de outras formas de controle social (ELIAS, 1994).

De acordo com Elias (1994, p. 198),

A moderação das emoções espontâneas, o controle dos sentimentos, a ampliação do espaço mental além do momento presente, levando em conta o passado e o futuro, o hábito de ligar os fatos em cadeias de causa e efeito - todos estes são distintos aspectos da mesma transformação da conduta, que necessariamente ocorre com a monopolização da violência física e a extensão das cadeias da ação e interdependência social. Ocorre uma mudança 'civilizadora' do comportamento.

Essa mudança "civilizadora" do comportamento se deu com o crescimento da interdependência humana, a partir dos processos de industrialização, urbanização e crescimento populacional com seus elos de intensificação da dependência mútua. Para Hochman (1998), essa dependência coletiva promoveu o abandono gradual das soluções individuais e potencializou as decisões de "custos de interdependência". Uma dessas decisões foi o combate "[...] das doenças, em especial quando se apresentava à sociedade sob a forma epidêmica" (1998, p. 51). Assim, a doença acabara "[...] por igualar e conectar todos os seres humanos e suas comunidades, em uma ampla cadeia de mútua dependência" (HOCHMAN, 1998, p. 50).

Desse modo, a própria formação de uma comunidade nacional "[...] está associada à extensão das cadeias de dependência recíproca". Assim, os elos de interdependência que fundariam a necessidade da coletivização do cuidado

[...] com os pobres, destituídos, desnutridos, doentes, iletrados ou quaisquer outros indivíduos que sofram adversidades temporárias ou permanentes, são os efeitos externos ou externalidades. Ou seja, as consequências indiretas das 
deficiências e adversidades de uns indivíduos sobre outros, que são imediatamente atingidos, apesar de não sofrerem dos mesmos problemas. Por exemplo, a ameaça da doença, do crime, da improdutividade e da rebelião causada pela pobreza e pela destituição de alguns, sobre os membros da sociedade (HOCHMAN, 1998, p. 25).

Por isso, é possível verificar que no currículo da CEAA e da CAASCI há um esforço de divulgação do sanitarismo brasileiro, como uma política de proteção pública e nacional, por meio da prevenção de contágio. Assim, só poderia ser justificada uma campanha de alfabetização de proporção nacional se ela viesse acompanhada de uma formação moral que transformasse o analfabeto em alguém produtivo, livre dos vícios e adaptável ao mundo social. Foi ancorada nessa defesa que a CEAA lançou seus fundamentos no plano político que combatia

[...] as ideias anárquicas e socialistas, pois 'as grandes massas, relegadas a um plano secundário de ignorância e estacionamento, eram presas fáceis de ideologias nocivas nas mãos de demagogos anarquistas'. Entretanto, uma vez reajustadas às suas inclinações, integradas nos grupos sociais a quem pertencem ou, ainda, sobrepujando o nível social desses mesmos grupos - pela capacidade adquirida - terão oportunidades de se tornarem participantes de uma vida melhor, úteis a si próprios, à coletividade e, consequentemente, ao país que lhes serviu de berço (PAIVA, 1983, p. 182).

Assim, a CEAA vinha como uma política do mundo urbano para as comunidades rurais, como um condutor dos parâmetros culturais, sociais, econômicos e políticos que, de certa forma, excluíam o modo de viver das comunidades rurais. Essa desvalorização crescente do modo de viver do meio rural, em relação ao urbano, produzia, ao mesmo tempo, "[...] o encontro e o choque entre valores e referências desses dois mundos" (ALMEIDA, 2005, p. 280).

Por isso, a Campanha realizada em Cachoeiro de Itapemirim destacou-se porque a responsável por ela, a professora Zilma, uniu outros elementos de ação social em prol da alfabetização, os quais aplacavam as resistências locais. Segundo a professora Zilma,

A princípio o trabalho era em escolas primárias do Estado, no meio rural, quando ao lado do ensino, procurávamos ver as necessidades individuais, como a fome, doenças causadas por verminoses que consequentemente levava-os a anemia, dificultando a aprendizagem. Conclui-se que o problema era coletivo. Foi necessário um trabalho junto aos recursos da comunidade e junto às famílias. Ensinamos os princípios mais elementares de higiene pessoal e do meio ambiente. Orientação quanto a alimentação, quando eram afastados os tabus alimentares. Não sabiam, no meio rural, aproveitar o que tinham e muitas vezes morriam de fome.

Posteriormente o trabalho foi dentro do município, que seguiu o mesmo processo educativo. Na cidade, além dos problemas do meio rural, contava-se com 
o desemprego e também o analfabetismo dos adultos, que não conseguiam emprego por não terem certificado de $4^{\circ}$ ano primário. Concluiu-se mais uma vez que o problema era coletivo.

O trabalho de mobilização da comunidade se deu em uma época em que as pessoas não eram conscientizadas para o trabalho comunitário. Ainda não existia televisão, pouquíssima infraestrutura, poucas instituições sociais. Para utilização de recursos da comunidade haviam maiores barreiras entre os dirigentes. Tudo era difícil e mais ainda, capacitar pessoas a integrar-se a uma ação organizada. Tinham que trabalhar num labirinto de ideias, valores, preconceitos e aspirações (CARVALHO; SILVA; JORDÃO, 1986, p. 9).

Além disso, no decorrer da campanha o envolvimento de profissionais como médicos, dentistas, advogados e outros produzia uma visibilidade aos sujeitos e às suas ações, projetando a importância social do exercício dessas profissões no serviço ao público da região.

A CAASCI foi administrada por uma diretoria que era eleita trienalmente pelos sócios-fundadores e contribuintes, composta pelos seguintes cargos: presidente, vice-presidente, $1^{\circ}$. secretário, $2^{\circ}$. secretário, $1^{\circ}$. tesoureiro e $2^{\circ}$. tesoureiro. A professora Zilma Coelho Pinto sempre foi a presidente da entidade, inclusive era a responsável pela redação do estatuto da entidade, prevendo as ações dessa função que ela ocupou até os últimos dias de sua vida. Suas atribuições, como presidente, foram:

\begin{abstract}
Representou a campanha em juízo e fora dela; encarregou de receber os auxílios oficiais do Governo, recebeu e assinou todos e quaisquer documentos, inclusive cheques. Autorizou despesas e vistoriou os documentos da tesouraria, rubricou os livros (caixas donativos de registros de sócios etc.), documentos de determinados trabalhos, apresentou anualmente relatório das atividades da Campanha; presidiu as reuniões da diretoria e da assembleias gerais, ordinárias e extraordinárias, com voto de desempate, enfim, supervisionou todas as medidas necessárias ao cumprimento deste Estatuto (ESTATUTO DA CAMPANHA DE ALFABETIZAÇÃO E ASSISTÊNCIA SOCIAL DE CACHOEIRO DE ITAPEMIRIM, [19--], capítulo 3, p. 2).
\end{abstract}

Na ocasião de sua fundação, a diretoria da CAASCI foi formada pelas seguintes pessoas e seus respectivos cargos: Zilma Coelho Pinto como presidente; Claudionor Ribeiro como vice-presidente; Adyr Miranda Madureira como 1º secretário; Théa Baptista como $2^{\circ}$. secretário; João Athayde como $1^{\circ}$. tesoureiro; e Lourival Sales como $2^{\circ}$. tesoureiro. ${ }^{10}$

A partir da criação da CAASCI, a movimentação de todos se deu em busca de uma doação de um terreno para a construção da sede da entidade, que pudesse oferecer instalações ao atendimento das classes já atendidas e outras a serem abertas ao público. Em 13 de junho

10 Conforme a professora Zilma Coelho Pinto, "[...] a presidência da Campanha sempre foi ocupada por ela, desde a fundação, os outros cargos eram modificados. Ela mesma manipulava a forma de eleição e convidava as pessoas para ocuparem os cargos. Nenhuma da diretoria que passou pela Campanha teve destaque, nunca encontrou ninguém com disposição para olhar e fiscalizar. Ela procurou trabalhar e fazer tudo" (CARVALHO; SILVA; JORDÃO, 1986, p. 17). 
de 1950 foi doado pelo prefeito do município, Dr. Dulcino Monteiro de Castro, um terreno com 22.998 metros quadrados, situado no bairro Aquidabã, em Cachoeiro de Itapemirim. A CAASCI foi representada, no ato de escrituração, por sua presidente, a professora Zilma Coelho Pinto. Na escritura, ainda constavam outras doações:

\begin{abstract}
O terreno doado pela presente escritura se destina à edificação das casas doadas pelo SESI - Serviço Especial de Indústria, de um grupo escolar pelo INEP - Instituto Nacional de Estudos Pedagógicos - e de outras edificações que venham a beneficiar a Campanha de Alfabetização e Assistência Social de Cachoeiro de Itapemirim (CARTÓRIO do $1^{\circ}$. Ofício de Cachoeiro de Itapemirim, registro $n^{\circ} .15 .439, L^{\circ} .3-X$ e FLs. 10,1).
\end{abstract}

Nessa escritura ainda é declarada a doação de um terreno medindo 6.762 metros quadrados à CAASCI, situado também no bairro Aquidabã, que havia sido doado pelo casal Anacleto Ramos e sua mulher Carly Levy Ramos ${ }^{11}$ à prefeitura do município de Cachoeiro de Itapemirim. Esse terreno seria destinado à construção de uma praça municipal de esportes, mas o casal citado "[...] estava de pleno acordo que o município de Cachoeiro de Itapemirim doasse, como fez pelo instrumento acima, parte dos referidos terrenos à Campanha de Alfabetização e Assistência Social de Cachoeiro de Itapemirim" (Cartório do $1^{\circ}$. Ofício de Cachoeiro de Itapemirim, registro $\mathrm{n}^{\circ} .15 .439, \mathrm{~L}^{\circ}$. 3-X e FLs. 10, 3).

De acordo com Silva (2009), para a construção da sede da CAASCI, a professora Zilma "[...] montou em carroceria de caminhão, ficou exposta sobre o assoalho de carroças, andou a cavalo ou a pé e pegou carona nos carros", recolhendo, em suas andanças pela cidade, "[...] refugos de madeira, telhas, folhas de zinco, resto de tijolos, latas vazias, sobras de tintas, enfim, tudo que pudesse ser útil a CAASCI, e isso lhe valeu o apelido de "cata lixo" e "mendiga no 1 "”. Além disso, em muitos momentos, "[...] empunhou a ferramenta bruta, ora para cavar a terra, ora para aplicar caiação nas paredes, que se iam levantando" (SILVA, 2009, p. 2).

Além disso, para aterrar o terreno pantanoso, os recursos humanos foram da própria comunidade, de acordo com a professora Zilma,

[...] a sistemática de trabalho foi a seguinte: A comunidade retirava a tabôa e fazia dos brotos desta alimento e do resto fazia-se esteiras as quais vendiam e tinham uma atividade remunerada. Os construtores mandavam terra para o aterro e só cobravam o combustível. Quando, em 1948, a Campanha começou a conseguir e instalar e lá vem D. Zilma dizendo: "Sabe lá Deus como. Antes de comprar, pediam materiais de construção nas lojas e a industriais, assim conseguiam por um preço melhor..." (CARVALHO; SILVA; JORDÃO, 1986, p. 10).

11 Segundo o professor Wilson Lopes de Resende, via contato telefônico, o francês Samuel Levy era o detentor de todas as terras onde foi construída a sede da CAASCI. Sua filha Carly Levy casou-se com o Anacleto Ramos. Como o casal não teve filhos, a herança das propriedades foi doada às instituições e ao Poder Público, com finalidades sociais.

Comunicações $\mid$ Piracicaba | v. $24 \mid$ n. 3 | p. 279-305 $\mid$ setembro-dezembro 2017 
A partir do trabalho no aterro do terreno para a construção da sede da CAASCI, feito pela população pobre de Cachoeiro de Itapemirim, a professora Zilma só aceitou que a CAASCI funcionasse a partir do encontro entre as finalidades educacionais, assistenciais e profissionalizantes para aquela camada populacional de sua região. Para a professora Zilma (CARVALHO; SILVA; JORDÃO, 1986, p. 14):

[...] tratou-se de um acordo feito com os pobres, onde ela propunha que se eles me ajudassem aterrar a área de construção da Campanha, eu iria fazer uma escola onde a filha do pobre pudesse aprender a ler e a escrever da mesma forma que a filha do rico.

A CAASCI obteve também substancial apoio da embaixada dos Estados Unidos na construção de sua sede. A embaixada doou "[...] as casas pré-fabricadas de madeira onde funcionavam os diversos departamentos da entidade; máquinas datilográficas; material de escritório; livros, cadernos e material escolar em geral" (GUEDES, 2010, s/p). Desse modo, a CAASCI abriu suas portas para atender a homens, mulheres e crianças, e ergueu sua sede em Cachoeiro de Itapemirim.

Diante da contribuição de muitos e do reconhecimento da CAASCI, a professora Zilma Coelho Pinto pronunciou-se em um artigo intitulado O agradecimento da Campanha de Alfabetização, que foi publicado num jornal local, Vanguarda, do dia 18 de novembro de 1948. O texto era destinado "[...] ao distinto e esclarecido povo de Cachoeiro de Itapemirim, bem como ao de todo o Brasil, que nos concedeu o seu valoroso apoio monetário e material" (PINTO, 1948, s/p). E continuou,

[...] quero em nome da Campanha de Alfabetização, por mim promovida em Cachoeiro de Itapemirim, e no de minhas abnegadas auxiliares, apresentar os nossos sinceros agradecimentos pela valiosa colaboração que nos deu, e a que se deve, sem dúvida, o êxito dessa campanha que, inegavelmente trouxe ao seio de nossa terra um surto de desenvolvimento e progresso.

Agradecemos, também, a Imprensa e a todos que tão bem souberam nos encorajar, enviando-nos as palavras de estímulo com que nos honraram. Sentimo-nos felicíssimas em poder dizer que o trabalho foi árduo, mas que os frutos foram bem compensados. Reconhecemos ter sido sacrifício para muitos o auxílio que nos concederam, porém, em Cachoeiro de Itapemirim decresceu o índice de analfabetos.

Desejo - em particular - dizer ao povo que tanto confiou em mim, que me apoiou com tanta bondade e convicção, no êxito do meu trabalho, que fez tudo por não desmerecer essa confiança e que me sentia sensibilizadíssima toda vez que recebia uma manifestação de um elevado apreço e confiança. É a ele, o povo, que devo o êxito do meu trabalho, animando-me moralmente e me impelindo para frente, a fim de não recuar diante das inúmeras peripécias que me depararam.

Muita vez, pensei confiaram em mim os cachoeirenses e não posso recuar. Assim, cheia de desenganos e cansaço, por vezes, prossegui na minha peleja. Portanto, é a todos que me incentivaram, dando-me, apoio que mais uma vez 
agradeço. Aos que me combateram expresso ainda o meu agradecimento pois, à maneira de Nietzsche 'tudo que não me mata me faz mais forte' e os convido, para, no próximo ano ajudarem-me na grande tarefa de redenção dos brasileiros, às trevas da ignorância.

Comunico, outrossim, que dentro em breve publicarei uma prestação e contas do meu trabalho (PINTO, 1948, s/p).

O reconhecimento e o agradecimento da participação popular de Cachoeiro de Itapemirim no envolvimento da tarefa de redenção nacional no combate "às trevas da ignorância”, por parte da presidente da CAASCI nos leva ao seguinte questionamento: essa participação e apoio popular se deram por via da assistência ou da prerrogativa da vida política pela adesão de uma política pública governamental, como o exercício de democracia, uma vez que o país passava, historicamente, por um período de redemocratização?

A partir da visibilidade, a Campanha de Alfabetização e de Assistência Social de Cachoeiro (CAASCI) alcançou relevante posição no setor educacional cachoeirense e na cena nacional. A sua atuação nas décadas de 1940 e 1950 permaneceu em notável prosperidade enquanto recebia verbas do Governo Federal, Estadual e Municipal. Desses repasses, o maior era o do Governo Federal que, em 1950, chegou a garantir a existência de diversos cursos (Figura 2), ministrados pela Campanha, como citado a seguir:

a) Duas classes de pré-primário;

b) Curso primário completo;

c) Admissão ao ginásio matutino e vespertino;

d) Ensino primário supletivo;

e) Curso de datilografia;

f) Iniciação agrícola, avicultura e cunicultura para crianças, adolescentes e adultos matriculados em seus diversos cursos (REVISTA BOAS NOTÍCIAS,1965, s/p).

E também realizava os seguintes trabalhos na comunidade local:

a) Educação agrícola, na própria comunidade, inclusive com manutenção do programa radiofônico "Aproveite seu quintal", na ZYL-9 dessa cidade, com distribuição e permuta de sementes, exibição de diafilmes e filmes educativos sobre saúde, higiene, avicultura, horticultura e serviço militar;

b) Palestras intensivas nos diversos cursos bem na comunidade, no sentido de aprimorar os hábitos de alimentação, saúde e orientação profissional;

c) Encaminhamento de alunos a empregos;

d) Cursos de economia doméstica;

e) Iniciação profissional constante de corte e costura, bordados diversos - tricot, crochet, pinturas diversas, decapé, cursos intensivos: juninos, pascoalinos, natalinos e outros de interesse geral;

f) Artesanato; 
g) Trabalho de assistência social consistindo no seguinte: distribuição de roupas, calçados, material e merenda escolar a alunos pobres, assistência médica e remédios, por meio do modesto ambulatório "Miguel Couto" para alunos e pessoas necessitadas. Orientação social e profissional para alunos e respectivas famílias e o público em geral;

h) Puericultura;

i) Educação artística;

j) Manutenção de duas bibliotecas franqueadas ao público em geral, uma para adultos e outra para crianças (REVISTA BOAS NOTÍCIAS,1965, s/p).

Figura 2 - Crianças e adolescentes atendidos pela professora Zilma e pela professora voluntária Antonia de Medeiros

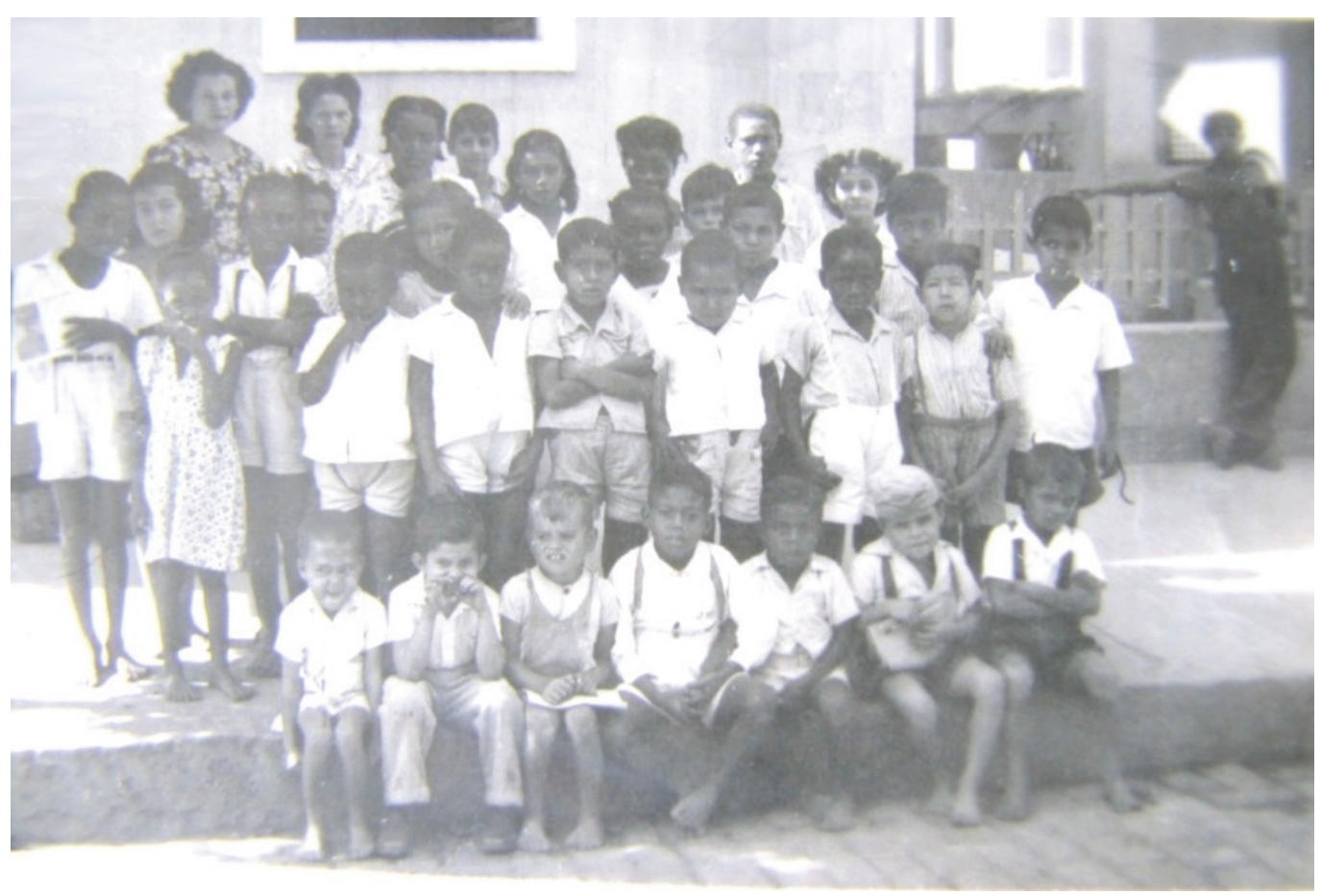

Fonte: Foto do arquivo pessoal de Sidney Gonçalves Netto Jordão

A partir dos anos de 1960, com a perda do apoio federal, a sede da CAASCI virou uma "bricolagem" de serviços, de programas sociais e políticos, como: consultórios médicos, Cartório de Registro Civil e Eleitoral, Juizado de Menores, Associação dos Pais e Amigos dos Excepcionais (APAE), orientação profissional, cursos da Legião Brasileira de Assistência (LBA) e projetos locais da Fundação Espírito-santense do Bem-Estar do Menor (FESBEM). 
As atividades desenvolvidas nas dependências da CAASCI com esses menores em "situação de risco" ou com uma "doença social"12 eram voltadas para a profissionalização e recreação desses adolescentes e jovens, como: artesanato em couro, recreação, reparador de aparelhos eletrodomésticos, manicure, pedicure, corte e costura. Além disso, eram reservadas salas para reunião e encontros dessa Fundação.

Desse modo, as tensões são múltiplas entre a reputação do povo que frequentava a CAASCI (analfabetos, "negrinhos" e "negrinhas" da professora Zilma, pobres, matutos e outros) e a sociedade tradicional de Cachoeiro de Itapemirim. Além desses estigmas negativos, que já circulavam na sociedade cachoeirense desde o final da década de 1940, com a criação da CAASCI mais um estigma passa a integrar a composição do povo atendido na entidade - a categoria "menor" que se associava à proteção do controle penal. Desse modo, eram sujeitos pertencentes à "classe perigosa", “[...] aqueles que necessitavam de alguma assistência. Fossem os 'abandonados', fossem aqueles que cometiam algum ato infracional - os infratores, ambos eram taxados de "menores"' (LOPES; SILVA; MALFITANO, 2011, p. 117). Assim, configurava-se uma legislação apenas para esses "menores", ou seja,

[...] para os que tinham 'menoridade social', crianças e adolescentes pobres. Esta imersão de duas diferentes situações sobre o rótulo 'menor' fez com que elas se tornassem miscigenadas, constituindo, assim, um imaginário popular sobre a infância e juventude que associava, e ainda associa, a pobreza e o delito, o abandono e a infração, reforçando um pensamento causal sobre origem de classe e condição jurídica de vida (LOPES; SILVA; MALFITANO, 2011, p. 117).

Por isso, defendeu a leitura como "possibilidade de redenção" do homem, aconselhando aos pais "dessa gurizada irresponsável" que fossem "às bancas de jornal e procurassem livrinhos interessantes assim à venda", que comprassem, lessem e despertassem em seus filhos a necessidade de aplicar os ensinamentos extraídos dos livros em casa. Nesse sentido, a professora valorizou, para além das ações situadas no âmbito da formação de conhecimentos formais, a leitura como um dispositivo voltado para a conformação de hábitos, valores e comportamentos.

Enfim, no trabalho da CAASCI, que passou por historicidades diferenciadas, pois teve o começo de sua atuação em 1948 e o seu término com a morte de sua fundadora, em $1986,{ }^{13}$ é possível perceber propostas de moldagem social em que um aspecto comum une os diversos tempos de atuação dessa entidade: a presença de um projeto civilizador, dotado de claro sentido normativo.

12 Termos utilizados nos laudos psicossociais.

13 De acordo com Carvalho, Silva e Jordão (1986, s/p), no ano de 1985 a professora Zilma estava com uma idade avançada e "[...] recebia conselhos de seus familiares para que abandonasse a Campanha, porque achavam que ela estava perdendo seu tempo e saúde, pois não possuía mais forças para trabalhar [...] sofrerá de trombose. Ela reconhecia essa realidade, mas sua obsessão era muito maior, o cansaço era grande, mas não entregou os pontos". 


\section{CONSIDERaÇões Finais}

O modelo de sociedade democrática proposto pela CEAA contava com um projeto que vinculou educação, saúde e civilização como um processo que deveria ser seguido com vistas a interagir e abrandar os hábitos sociais existentes tidos como "males sociais". A atuação da professora Zilma e das demais docentes voluntárias apresentadas nesta pesquisa foi guiada pela ideia de que o domínio da leitura e da escrita acrescentava imediatamente as noções de higiene geral como medidas sanitárias, erradicação de vícios, modulação da família e o cultivo das "boas práticas morais e normas cívicas".

Essas expectativas eram cercadas de pressões quanto aos modos de se comportar dos "analfabetos" que, no caso brasileiro, tratava-se de um grupo composto de mais de $56 \%$ de toda a população com mais de 15 anos de idade. Para Elias (1997), o exame das coações a que as pessoas estão expostas é central no entendimento dos problemas da humanidade. $\mathrm{O}$ grau e o padrão de ativação das coações "[...] dependem da sociedade em que uma pessoa cresce, e muda, de modos específicos, ao longo do processo contínuo de desenvolvimento humano" (ELIAS, 1997, p. 43). Dessa forma, o processo civilizatório é trabalhado por Elias $(1993,1994,1997)$ numa perspectiva de construção histórica e não como algo dado historicamente.

Entre as várias ações construídas e recomendadas pelo Ministério da Educação e Saúde, destacamos o lançamento oficial, a partir de 1947, da primeira Campanha de Educação de Adolescentes e Adultos em todo o país, contando com a direção geral do professor Lourenço Filho, um dos eminentes educadores brasileiros do início do século XX, que participou ativamente da constituição das ideias pedagógicas da CEAA.

Entendemos que a sua participação na CEAA tratou novamente da crença dele e de outras vozes da intelectualidade nacional e internacional, de que a produção científica educacional podia conduzir o processo de organização da nação brasileira, insatisfeita com os rumos tomados pelos princípios doutrinários postos em prática durante o regime do Estado Novo. A alfabetização passou a ser identificada como um campo de ação da organização sanitária moderna por meio de um "ethos" de civilidade, agora na área de educação de jovens e adultos.

Nessa direção, desde o século XIX a proposição da alfabetização da CEAA como parte integrante do curso civilizatório brasileiro já em andamento propôs determinadas questões centrais, como: a construção da imagem do "homem brasileiro" por meio do Ministério da Educação e Saúde, a partir da defesa da educação, pátria e saúde, como condições "ideais" para se alcançar comportamentos desejáveis, que consagraram o papel da educação na tarefa preventiva contra a "barbárie" (COSTA, 2012; 2016).

Desse modo, ficou mais coerente a análise da atuação da professora Zilma Coelho Pinto como alfabetizadora nas escolas rurais do município de Cachoeiro de Itapemirim no Estado do Espírito Santo. Ela ganhou notoriedade internacional e nacional, ao criar uma entidade sem fins lucrativos, que tinha como objetivo primordial o fim do analfabetismo em sua região. A Campanha de Alfabetização e Assistência Social de Cachoeiro de Itapemirim 
contou com o apoio financeiro e pedagógico do Ministério da Educação e Saúde durante a vigência da CEAA.

Em suma, a CAASCI respondeu a exigências muito justas e profundamente éticas do seu tempo, ao alfabetizar e prestar assistência às crianças, jovens e adultos das comunidades rurais afastadas daquela região, que, desejosos de orientação médica, social e educacional, se matriculavam nessas classes de alfabetização e de iniciação profissional. A proposta da professora Zilma Coelho Pinto de que a CAASCI seria uma escola onde o filho do pobre pudesse aprender a ler e a escrever do mesmo modo que o filho do rico intensificou o apoio dessas comunidades rurais no envio de seus filhos e de famílias inteiras para o estudo das primeiras letras nas classes organizadas pelas professoras.

A concepção de educação da CAASCI era semelhante à da CEAA, que foi apresentada como a possibilidade de "redenção" do homem brasileiro. Os adolescentes, jovens e adultos atendidos por essa entidade foram considerados seres em desenvolvimento que podiam ser moldados para atender às demandas sociais, ou seja, para ocupar os lugares que thes foram destinados pelo desenvolvimento natural da sociedade.

É importante destacar que Lourenço Filho, como o primeiro diretor da CEAA, e a professora Zilma Coelho Pinto, premiada como uma das melhores experiências pedagógicas da CEAA dos municípios brasileiros, foram porta-vozes da defesa da alfabetização como parte integrante do processo de incorporação de hábitos, assimilação de determinados padrões de conduta e de comportamentos "aceitáveis" à organização de uma nação desenvolvida. Isso resultou na associação de que o domínio da leitura e da escrita era também virtude moral dos indivíduos.

Com isso, de algum modo, a luta contra o analfabetismo correu o risco de se transformar em luta contra os analfabetos, que foram identificados nas produções pedagógicas da CEAA como improdutivos, degenerados, servis, viciados e incapazes. Desse modo, as origens dos problemas sociais, econômicos, políticos e históricos do país eram mascaradas e justificadas pela atribuição de que o único problema nacional era a educação do seu povo.

\section{REFERÊNCIAS}

ALMEIDA, Dóris Bittencourt. A educação rural como processo civilizador. In: STEPHANOU, Maria; BASTOS, Maria Helena Camara (Org.). Histórias e memórias da educação no Brasil: século XX. Rio de Janeiro: Vozes, 2005, v. III, p. 278-295.

AZEVEDO, Thales de. A religião civil brasileira: um instrumento político. Petrópolis: Vozes, 1981.

BEISIEGEL, Celso Rui. Estado e educação popular: um estudo sobre a educação de adultos. Brasília: Líber Livro, 2004.

CARONE, Gilson. Vulto em nossa cidade a Campanha de Alfabetização, 8 de jun. de $1948, \mathrm{~s} / \mathrm{p}$. 
Cartório do $1^{\mathrm{o}}$. Ofício de Cachoeiro de Itapemirim, registro $\mathrm{n}^{\mathrm{o}}$. 15.439, $\mathrm{L}^{\circ}$. 3-X e FLs. 10, 3. Criação da CAASCI, [19--] (Mimeografado).

CARVALHO, Carlos Geraldo; SILVA, Elza Helena da; JORDÃO, Sidney Gonçalves Netto. Zilma Coelho Pinto e a Campanha de Alfabetização. Cachoeiro de Itapemirim, 1986 (Mimeografado).

COSTA, Deane Monteiro Vieira. A Campanha de Educação de Adolescentes e Adultos no Brasil e no Estado do Espírito Santo (1947-1963): um projeto civilizador, 2012.245s. Tese (Doutorado em Educação) - Universidade Federal do Espírito Santo. Vitória, 2012.

. A Campanha de Educação de Adolescentes e Adultos no Brasil e no Estado do Espírito Santo (1947-1963): um projeto civilizador. São Carlos: Pedro \& João Editores, 2016.

COSTA, Deane Monteiro Vieira. Cachoeiro de Itapemirim: um clube republicano e um herói. Revista do Instituto Histórico Geográfico do Espírito Santo. Vitória: IHGES, 2000.

COSTA, Gilda de Araujo. A educação na assembleia constituinte do Espírito Santo de 1947. Trabalho apresentado no IV Seminário Nacional de Estudos e Pesquisas "História, Sociedade e Educação no Brasil”. São Paulo: UNICAMP, 1997. Disponível em: <http:// www.histedbr.fae.unicamp.br/acer_histedbr/seminario/seminario4/trabalhos.htm $>$. Acesso em: $1^{\circ}$. out. 2010.

ELIAS, Norbert. A sociedade dos indivíduos. Rio de Janeiro: Zahar, 1994a.

ELIAS, Norbert. O processo civilizador: formação do Estado e civilização. Rio de Janeiro: Zahar, 1993.

ELIAS, Norbert. O processo civilizador: uma história dos costumes. Rio de Janeiro: Zahar, 1994.

ELIAS, Norbert. Os alemães: a luta pelo poder e a evolução do habitus nos séculos XIX e XX. Rio de Janeiro: Zahar, 1997.

ESTATUTO da Campanha de Alfabetização e Assistência social de Cachoeiro de Itapemirim, [19--] (Mimeografado).

FÁVERO, Osmar. Memória das campanhas e movimentos de educação de jovens e adultos (1947-1966). Disponível em: <http://www.forumeja.org.br/df/files/leiamais.apresenta. pdf>. Acesso em: 10 out. 2010.

FRANCO, Sebastião Pimentel. As escolas femininas de formação para o magistério no Espírito Santo: Primeira República. Disponível em: $<$ http://www.ufes.br/ppghis/dimensoes/artigos/dimensoes16_sebastiaopimentelfranco.pdf $>$. Acesso em: 4 mar. 2011.

GINZBURG, Carlo. Relações de força: história, retórica, prova. São Paulo: Companhia das Letras, 2002. 
GRAFF, Harvey J. Os labirintos da alfabetização: reflexões sobre o passado e o presente da alfabetização. Porto Alegre: Artes Médicas, 1994.

GUEDES, Ruy. A louca de Itapemirim. Disponível em: <www.atenasnoticias.com.br/ site/conteudo.asp?codigo=17679>. Acesso em: 4 dez. 2010.

HOCHMAN, Gilberto. A era do saneamento: as bases da política de saúde pública no Brasil. São Paulo: Hucitec / Anpocs, 1998.

LA LOCA de la escuela: Campaña contra el analfabetismo en el Brasil. Revista El Correo: Publicación de la Organización de las Naciones Unidas para la Educacion, la Ciência y la Cultura, v. III, n. 8, p. 12. Disponível em: http://unesdoc.unesco.org/images/008/00815/081543/so.pdf>. Acesso em: 28 abr. 2010.

LAZZARO, Agostino. A face múltipla e vária: a presença da mulher na cultura capixaba. Vitória: Academia Feminina Espírito-Santense de Letras, 1994.

LOPES; Roseli Esquerdo; SILVA, Carla Regina; MALFITANO, Ana Paula Serrata. Adolescência e juventude de grupos populares urbanos no Brasil e as políticas públicas: apontamentos históricos. Disponível em: $<$ http://www.histedbr.fae.unicamp.br/revista/edicoes/23/art08_23.pdf>.Acesso em: $1^{\circ}$. abr. 2011.

LOURENÇO FILHO, Manoel Bergstron. Introdução à educação de adultos. In: BRASIL. Departamento de Nacional de Educação. Campanha de Educação de Adultos. Fundamentos e metodologia do ensino supletivo. Rio de Janeiro: Ministério da Educação e Saúde, 1950, p. 3-19.

LOURENÇO FILHO, Manoel Bergstron. La formation des mâitres ruraux. problèmes d'education. Paris: UNESCO, 1953, v. VII.

MACIEL, Manoel Gonçalves. Voltando ao Cachoeiro antigo. Cachoeiro de Itapemirim: Editora e Gráfica Gracal, 2003, v. II.

PAIVA, Vanilda Pereira. Educação popular e educação de adultos. São Paulo: Loyola, 1983.

PINTO, Zilma Coelho. O agradecimento da Campanha de Itapemirim. Vanguarda, Cachoeiro de Itapemirim, 18 nov. 1948.

REVISTA BOAS NOTÍCIAS. Zilma Coelho Pinto: a idealista $n^{\circ} .1$ do Brasil, quiçá do mundo hodierno! Out. 1965.

ROCHA, Haroldo Corrêa; MORANDI, Angela Maria. Cafeicultura e Grande Indústria: a transição no Espírito Santo 1955-1985. Vitória: Fundação Ceciliano Abel de Almeida, 1991.

SILVA, Marta Zorzal e. Espírito Santo: estado, interesse e poder. Vitória: Fundação Ceciliano Abel de Almeida/ Secretaria de Produção e Difusão Cultural (UFES), 1995. 
SOARES, Leôncio José Gomes. Educação de adultos em Minas Gerais: continuidades e rupturas, 1995, 282s. Tese (Doutorado em Educação) - Universidade de São Paulo, São Paulo, 1995.

VEIGA, Cynthia Greive. Pensando com Elias as relações entre sociologia e história da educação. In: FARIA FILHO, Luciano Mendes (Org.). Pensadores sociais e História da educação. Belo Horizonte: Autêntica, 2008.

\section{DADOS DA AUTORA}

\section{DEANE MONTEIRO VIEIRA COSTA}

Doutora em Educação pela Universidade Federal do Espírito Santo. Coordenadora do Núcleo de estudos sobre Educação, Trabalho e Juventudes do Instituto Federal do Espírito Santo. Vila Velha/ES - Brasil. deaneescoladegestores@gmail.com

Submetido em: 4-7-2017

Aceito em: 10-11-2017 